\title{
PENGARUH PENDIDIKAN KARAKTER DALAM PEMBELAJARAN AKUNTANSI KEUANGAN TERHADAP SIKAP ETIS MAHASISWA
}

\author{
Mohammad Ghofirin \\ Fakultas Ekonomi dan Bisnis, Universitas Nahdlatul Ulama Surabaya \\ e-mail: ghofie@unusa.ac.id
}

\begin{abstract}
Character education is an education that is oriented not only to the mastery of teaching science (knowledge) but also the noble character (good character). The purposes of the study was to investigate the effect of character education which is integrated in financial accounting teaching and learning process to the students' ethical attitudes. The results of the study showed that character education doesn't affects students' ethical attitudes (Sig $0.65>0.05$ ). Therefore, it can be concluded from this study that character education integrated in financial accounting teaching and emotional intelligence affects the students' ethical attitudes. The suggestions derived from the results of this study are: (1) For Accounting Department, State University of Malang, character education should be integrated explicitly on the whole subject of accounting department. (2) For lecturers, it is suggested to be willing and actively integrate character education in accounting teaching. (3) For other researchers, further research to examine the relationship between two independent variables is needed to be conducted. Therefore, it can be known whether one of the variables serve as a mediating or moderating variable.
\end{abstract}

\section{PENDAHULUAN}

Penyelenggaraan pendidikan di Indonesia dewasa ini semakin melupakan pesan-pesan etika dan moralitas. Pendidik lebih sebagai pengajar yang menitikberatkan pada pencapaian materi daripada pencapaian kualitas kepribadian peserta didik. Mahasiswa dituntut untuk menguasai materi yang diajarkan tanpa memedulikan ajaran nilai-nilai baik atau buruk, dan benar atau salah. Akibatnya, banyak lulusan yang pandai namun tidak memiliki kepribadian yang baik, banyak lulusan yang menguasai materi namun tidak memedulikan benar atau salah. Lulusan semacam ini cenderung akan menggunakan kepandaiannya untuk menguntungkan kepentingan diri sendiri walaupun harus mengorbankan kepentingan orang lain.

Cerdas saja tidak cukup tanpa didasari dengan etika dan moralitas. Terbongkarnya kasus mafia pajak yang dilakukan oleh karyawan Dinas Pajak (2010), dan kasus mafia perbankan yang dilakukan karyawan Citibank (2011) memberi kesadaran pentingnya dunia pendidikan dalam menciptakan sumber daya manusia yang cerdas dan bermoral. Selain kasus mafia pajak dan mafia perbankan, kasus penipuan dan amoral ekonomi di tanah air terjadi juga pada kasus penjualan Indosat (2002), kasus BULOG (1999), kasus BLBI (1998) serta kas daerah yang difungsikan untuk kepentingan pribadi para pejabat melalui suatu skenario pinjaman.

Dalam dunia kerja, potensi penipuan sangat mungkin dilakukan justru oleh akuntan yang menguasai ilmu akuntansi. Penelitian yang dilakukan oleh ACFE (Association of Certified Fraud Examiners) sebagaimana tertuang dalam buku Accounting Information Systems karya James A. Hall (2007:164) telah memeriksa sejumlah faktor yang mencirikan pelaku penipuan termasuk pendidikan pelaku penipuan. Hasil penelitian menyebutkan bahwa penipuan yang dilakukan oleh lulusan Universitas rata-rata lebih tinggi 
dibandingkan dengan penipuan yang dilakukan oleh lulusan SMU. ACFE menyimpulkan bahwa potensi penipuan meningkat sejalan dengan lamanya pendidikan yang diterima.

Pendidik dituntut tidak hanya mengajarkan penguasaan disiplin ilmu, namun harus diiringi dengan pendidikan yang memuat nilai etika, dan profesionalisme. Yani (1998) mengusulkan bahwa "untuk menciptakan akuntan yang beretika dan profesional harus dimulai dari pendidikan." Adapun bobot pengajaran tentang etika dan profesionalisme di jurusan akuntansi pada perguruan tinggi harus cukup memadai untuk dapat memberi bekal pemahaman tentang etika dan profesionalisme. Farhan (2009:45) menyatakan bahwa "persepsi akuntan terhadap kode etik mempunyai peranan penting dalam penegakan etika." Persepsi akuntan terhadap kode etik dapat terbentuk melalui suatu proses panjang yang dimulai dari pendidikan sebelum akuntan benar-benar aktif di dunia kerja.

Kurikulum akuntansi hendaknya tidak hampa dari muatan-muatan nilai etika. Kurangnya muatan etika dalam kurikulum akuntansi diungkapkan oleh Wulandari dan Sularso (2002) yang melakukan penelitian di Surakarta dengan sampel mahasiswa dan akuntan pendidik. Penelitian ini bertujuan mengetahui muatan pendidikan etika dan moral dalam kurikulum akuntansi. Hasil penelitian menunjukkan bahwa 84,38\% (dari 192 responden) menyatakan kurikulum program studi akuntansi belum cukup memberikan muatan etika untuk bekal mahasiswa terjun ke dunia kerja. Untuk responden yang menyatakan tidak cukup muatan etikanya menyarankan agar: (1) diperluas dengan mengintegrasikan ke mata kuliah tertentu (46,9\%), (2) diperluas dengan mengintegrasikan ke semua mata kuliah $(29,01 \%)$, (3) ditambah sebagai mata kuliah tersendiri $(18,52 \%)$ dan (4) pendapat lain (5,56\%). Hasil penelitian Ludigdo dan Machfoedz (1999) juga mengungkapkan muatan etika dalam kurikulum pendidikan akuntansi belum cukup dan sebagian besar responden menyarankan untuk mengintegrasikan ke mata kuliah tertentu.

Dewasa ini, di Indonesia sedang dikembangkan model pendidikan karakter. Pendidikan karakter dalam pembelajaran akuntansi dapat dilakukan dengan cara memasukkan nilai/karakter baik (good character) dalam proses perencanaan, pelaksanaan dan penilaian pembelajaran akuntansi. Nilai/karakter dikaji kemudian dimasukkan ke dalam silabus, satuan acara perkuliahan (SAP), dan rencana pelaksanaan pembelajaran (RPP).

Pendidikan karakter yang diintegrasikan dalam pembelajaran akuntansi dimaksudkan untuk melahirkan sumber daya manusia yang unggul bukan hanya dari segi intelektualnya, tetapi juga dari segi watak dan kepribadiannya. Wiwik Utami \& Fitri Indriawati (2006) melakukan eksperimen semu di Fakultas Ekonomi Universitas Mercu Buana dengan subjek penelitian adalah mahasiswa yang sedang menempuh mata kuliah akuntansi keuangan. Penelitian ini bertujuan mengkaji dampak pemberian muatan etika dalam pembelajaran akuntansi keuangan terhadap persepsi etika mahasiswa dikaitkan dengan prestasi mahasiswa. Hasil penelitian mengungkapkan bahwa interaksi muatan etika yang diintegrasikan dalam pembelajaran akuntansi keuangan dengan prestasi mahasiswa mampu meningkatkan sensivitas mahasiswa terhadap isuisu etika. Sementara itu, Jihad (2009:12) menyatakan bahwa "perkembangan tingkah laku seseorang adalah berkat pengaruh dari lingkungan sekolah/universitas." Lebih lanjut Hitlebeitel \& Jones (1992) menyimpulkan bahwa "pengambilan keputusan etis mahasiswa dipengaruhi oleh mata kuliah etika." Demikian juga O’Leary (2009) menyimpulkan bahwa "pengajaran etika akuntansi mempunyai pengaruh terhadap peng- 
ambilan keputusan etis.” Dengan demikian diduga bahwa pendidikan karakter yang diintegrasikan dalam pembelajaran akuntansi keuangan berpengaruh terhadap sikap etis mahasiswa akuntansi.

Berdasarkan uraian di atas, peneliti termotivasi untuk mengkaji "Pengaruh Pendidikan Karakter dalam Pembelajaran Akuntansi Keuangan”. Penelitian ini berangkat dari masih terbatasnya kajian tentang implementasi pendidikan karakter dalam pelaksanaan pembelajaran di kelas. Dosen belum terbiasa mengintegrasikan nilai/karakter dalam pengajaran mata kuliah tertentu, khususnya mata kuliah akuntansi. Integrasi pendidikan karakter baru sebatas wacana dan belum secara operasional diterapkan oleh civitas akademika. Penelitian ini juga termotivasi oleh beberapa kesenjangan hasil penelitian terdahulu, di antaranya yang dilakukan oleh Wulandari dan Sularso (2002) serta Ludigdo dan Machfud (1999) yang menyarankan agar mengintegrasikan muatan etika dalam mata kuliah tertentu. Sedangkan, penelitian yang dilakukan oleh Utami dan Indriawati (2006) menyimpulkan "muatan etika tidak berpengaruh terhadap persepsi etika mahasiswa." Baihaqi (2002) meneliti pengaruh Kecerdasan emosional (EQ) terhadap perilaku yang menunjukkan hasil bahwa "Kecerdasan emosional (EQ) berpengaruh signifikan terhadap perilaku." Sedangkan Tikollah M Ridlwan, dkk (2006) menyimpulkan "secara parsial kecerdasan emosional tidak berpengaruh terhadap sikap etis.”

Penelitian ini dilakukan terhadap mahasiswa akuntansi di Jurusan Akuntansi Fakultas Ekonomi (FE) Universitas Negeri Malang (UM) Tahun Akademik 2011/2012. Penelitian ini diharapkan mampu memberi kontribusi tentang integrasi pendidikan karakter dalam pembelajaran akuntansi keuangan di FE UM. Sehingga dapat memberikan bekal kepada mahasiswa akuntansi agar senantiasa bersandar kepada kode etik akuntansi dalam menjalankan profesi sebagai akuntan kelak di dunia kerja. Integrasi yang dimaksud adalah dengan memasukkan muatan nilai-nilai karakter pada silabus, satuan acara perkuliahan, dan rencana pelaksanaan pembelajaran.

\section{KERANGKA TEORETIS}

Pada bagian ini dikemukakan beberapa kajian teoretis yang melandasi penelitian ini, mencakup tentang konsep sikap etis dan pendidikan karakter.

\section{Sikap Etis}

Sikap etis merupakan sikap yang sesuai dengan etika. Hal ini didasarkan pada arti etis secara bahasa yakni berhubungan (sesuai) dengan etika; sesuai dengan asas perilaku yang disepakati secara umum.

Pada bagian ini akan dikemukakan konsep sikap, konsep etika dan kode etik akuntan.

\section{a. Konsep Sikap}

Sikap dalam Kamus Lengkap Bahasa Indonesia didefinisikan sebagai perbuatan dan sebagainya yang berdasarkan pendirian, pendapat, atau keyakinan. Sedangkan sikap dalam kamus psikologi merupakan kecenderungan untuk memberi respons, positif maupun negatif terhadap orang-orang, benda-benda, atau situasi-situasi tertentu (Tim Widyatama, 2010). Kedua definisi di atas memberi suatu gambaran bahwa sikap terbentuk berdasarkan pendirian untuk memberi respons positif atau negatif terhadap suatu objek.

Para ahli psikologi sosial mutakhir mendefinisikan sikap dalam dua pendekatan. Pendekatan pertama diwakili oleh Breckler, Katz \& Stotland, dan Rajecki dalam Azwar (2010:6) 
yang memandang bahwa "sikap sebagai kombinasi reaksi afektif, perilaku dan kognitif (tricomponent) terhadap suatu objek." Ketiga komponen tersebut secara bersama mengorganisasikan sikap individu. Sedangkan pendekatan kedua diwakili oleh Fishbein \& Ajzen, Oskamp, Petty \& Cacioppo dalam Azwar (2010:6) yang memandang bahwa "sikap terbatas pada aspek afektif saja (single comnponent)." Menurut pengikut pendekatan ini sikap didefinisikan sebagai afek atau penilaian positif-negatif terhadap suatu objek. Kedua pendekatan tersebut memberi suatu penegasan bahwa sikap merupakan konstruk multidimensional yang menempatkan aspek afektif mengungguli aspek kognitif dan konatif.

Lebih lanjut Jogiyanto (2007:36) mendefinisikan sikap (attitude) sebagai "evaluasi kepercayaan (belief) atau perasaan positif atau negatif dari seseorang jika harus melakukan perilaku yang akan ditentukan." Fishbein dan Ajzen (1975) dalam (Jogiyanto, 2007:36) mendefinisikan sikap sebagai berikut.

Sikap sebagai jumlah dari afeksi (perasaan) yang dirasakan seseorang untuk menerima atau menolak suatu objek atau perilaku dan diukur dengan suatu prosedur yang menempatkan individual pada skala evaluatif dua kutub, misalnya baik atau jelek, setuju atau menolak, dan lainnya.

Definisi-definisi tersebut menunjukkan bahwa secara garis besar sikap berada pada ranah pemikiran, belum sampai kepada perilaku. sikap memengaruhi perilaku melalui proses pengambilan keputusan yang teliti dan beralasan serta terencana.

\section{b. Konsep Etika}

Etika dalam Kamus Lengkap Bahasa Indonesia didefinisikan sebagai ilmu tentang apa yang baik dan apa yang buruk dan tentang hak dan kewajiban moral/akhlak. Sedangkan etika dalam kamus ilmiah populer didefinisikan sebagai pengkajian soal moralitas atau terhadap nilai tindakan moral (Dahlan, 2001). Farhan (2009: 11) mendefinisikan etika sebagai "nilai-nilai tingkah laku atau aturan-aturan tingkah laku yang diterima dan digunakan oleh individu atau suatu golongan." Etika dapat bersumber dari aturan agama, norma-norma, kebudayaan dan kearifan lokal masyarakat. Dengan demikian, etika dapat diartikan sebagai aturan perilaku tentang hal baik yang harus dilakukan dan hal buruk yang harus ditinggalkan.

Bertens (2002:6) membedakan etika dalam tiga arti, yaitu pertama, Etika diartikan sebagai nilai-nilai dan norma-norma moral yang menjadi pegangan bagi seseorang atau suatu kelompok dalam mengatur tingkah lakunya. Kedua, etika diartikan sebagai kumpulan asas atau nilai moral (kode etik). Dan Ketiga, Etika diartikan sebagai ilmu tentang yang baik atau buruk. Ketiga definisi Bartens di atas memiliki penempatan fungsi yang berbeda, arti pertama difungsikan sebagai sistem nilai pada taraf hidup perorangan maupun sosial. Arti kedua difungsikan sebagai kode etik bagi komunitas tertentu. Sedangkan arti ketiga difungsikan sebagai ilmu.

Dalam penelitian ini, etika diartikan sebagai seperangkat aturan, prinsip moral, atau nilainilai yang ditetapkan oleh organisasi profesi, dalam hal ini Ikatan Akuntan Indonesia, yang bertujuan untuk melindungi kepentingan anggota dan para pengguna jasa akuntan.

\section{c. Kode Etik Akuntan}

Kode etik adalah produk kesepakatan yang mengatur tingkah laku moral suatu kelompok tertentu dalam masyarakat untuk diberlakukan dalam suatu masa tertentu, dengan ketentuan tertulis yang diharapkan akan dipegang teguh oleh seluruh anggota kelompok (Farhan, 2009: 22). 
Ikatan Akuntan Indonesia (IAI) sebagai organisasi profesi di bidang akuntansi di Indonesia memiliki Kode Etik yang mengikat para anggotanya. Prinsip etika profesi dalam Kode Etik Ikatan Akuntan Indonesia menyatakan pengakuan profesi akan tanggung-jawabnya kepada publik, pemakai jasa akuntan, dan rekan. Prinsip ini memandu anggota IAI dalam memenuhi tanggung jawab profesionalnya dan merupakan landasan dasar perilaku etika dan perilaku profesionalnya.

Kode Etik IAI sebagaimana ditetapkan dalam Kongres VIII IAI di Jakarta pada tahun 1998 terdiri dari tiga bagian, yaitu: (a) prinsip etika, (b) aturan etika, dan (c) interpretasi aturan etika.

Prinsip-prinsip etika profesi dalam Kode Etik IAI adalah sebagai berikut.

- Prinsip Pertama - Tanggung Jawab Profesi

Dalam melaksanakan tanggung-jawabnya sebagai profesional, setiap anggota harus senantiasa menggunakan pertimbangan moral dan profesional dalam semua kegiatan yang dilakukannya.

\section{- Prinsip Kedua - Kepentingan Publik}

Setiap anggota berkewajiban untuk senantiasa bertindak dalam kerangka pelayanan kepada publik, menghormati kepercayaan publik, dan menunjukkan komitmen atas profesionalisme.

- Prinsip Ketiga - Integritas

Untuk memelihara dan meningkatkan kepercayaan publik, setiap anggota harus memenuhi tanggung jawab profesionalnya dengan integritas setinggi mungkin.

- Prinsip Keempat - Objektivitas.

Setiap anggota harus menjaga objektivitasnya dan bebas dari benturan kepentingan dalam pemenuhan kewajiban profesionalnya.

- Prinsip Kelima - Kompetensi dan Kehatihatian Profesional
Setiap anggota harus melaksanakan jasa profesionalnya dengan kehati-hatian, kompetensi dan ketekunan, serta mempunyai kewajiban untuk mempertahankan pengetahuan dan keterampilan profesional pada tingkat yang diperlukan untuk memastikan bahwa klien atau pemberi kerja memperoleh manfaat dari jasa profesional yang kompeten berdasarkan perkembangan praktik, legislasi, dan teknik yang paling mutakhir.

- Prinsip Keenam - Kerahasiaan

Setiap anggota harus menghormati kerahasiaan informasi yang diperoleh selama melakukan jasa profesional dan tidak boleh memakai atau mengungkapkan informasi tersebut tanpa persetujuan, kecuali bila ada hak dan kewajiban profesional atau hukum untuk mengungkapkannya.

- Prinsip Ketujub - Perilaku Profesional Setiap anggota harus berperilaku yang konsisten dengan reputasi profesi yang baik dan menjauhi tindakan yang dapat mendiskreditkan profesi.

- Prinsip Kedelapan - Standar Teknis

Setiap anggota harus melaksanakan jasa profesionalnya sesuai dengan standar teknis dan standar profesional yang relevan. Sesuai dengan keahliannya dan dengan berhati-hati, anggota mempunyai kewajiban untuk melaksanakan penugasan dari penerima jasa selama penugasan tersebut sejalan dengan prinsip integritas dan objektivitas.

Etika profesi yang dikeluarkan oleh Ikatan Akuntan Indonesia tidak hanya mengatur anggotanya yang berpraktik sebagai akuntan publik saja, namun mengatur perilaku semua anggotanya yang berpraktik dalam berbagai tipe profesi akuntan yang lain seperti akuntan manajemen, akuntan pendidik, dan akuntan pemerintah. 
Mahasiswa jurusan akuntansi diharapkan menjadi lulusan yang berkompeten di bidang akuntansi dan memahami serta mau melaksanakan etika profesi yang dijalani.

Berdasarkan uraian di atas, peneliti menggunakan delapan prinsip etika profesi Ikatan Akuntan Indonesia yang terdiri dari: (1) tanggung jawab profesi, (2) kepentingan publik, (3) integritas, (4) objektivitas, (5) kompetensi dan kehati-hatian profesional, (6) Kerahasiaan, (7) perilaku profesional, dan (8) standar teknis sebagai indikator untuk mengembangkan instrumen penelitian.

\section{METODE PENELITIAN}

Rancangan penelitian yang digunakan dalam penelitian ini adalah penelitian eksperimen dengan desain faktorial (factorial design). Sugiyono (2010:107) mendefinisikan metode penelitian eksperimen sebagai "metode penelitian yang digunakan untuk mencari pengaruh perlakuan tertentu terhadap yang lain dalam kondisi yang terkendalikan." Desain faktorial merupakan desain yang dapat memberikan perlakuan dua variabel bebas atau lebih pada waktu bersamaan untuk melihat efek masing-masing variabel bebas, secara terpisah dan secara bersamaan, terhadap variabel terikat dan efek yang terjadi akibat adanya interaksi beberapa variabel.

Penelitian ini menggunakan eksperimen karena tujuan penelitian ini adalah untuk mengetahui dampak dari suatu perlakuan (treatment) yaitu integrasi pendidikan karakter dalam pembelajaran akuntansi keuangan pokok bahasan Piutang dan Persediaan (kelompok treatment) dibandingkan dengan sekelompok mahasiswa lain (kelompok control) yang tidak memperoleh perlakuan.

\section{Sampel dan Prosedur Penelitian}

Populasi penelitian adalah mahasiswa Jurusan Akuntansi Fakultas Ekonomi Universitas Negeri Malang Tahun Akademik 2016/2017. Jumlah populasi sebanyak 1.046 mahasiswa yang terbagi dalam 27 kelas. Jurusan akuntansi memiliki karakteristik materi perkuliahan yang perlu mendapat muatan nilai etika. Mahasiswa sebelum ke dunia kerja, perlu dibekali dengan nilai etika dan moralitas, agar kelak menjadi tenaga profesional yang berperilaku sesuai dengan prinsip etika akuntan.

\section{Variabel Penelitian dan Pengukuran}

Variabel dalam penelitian ini adalah pendidikan karakter (X) dan sikap etis (Y). Pendidikan karakter merupakan variabel independen, sedangkan sikap etis merupakan variabel dependen. Variabel pendidikan karakter diintegrasikan ke dalam pembelajaran mata kuliah akuntansi keuangan. Sedangkan variabel sikap etis diukur dengan menggunakan kuesioner.

\section{Analisis Regresi Linier Berganda}

Berdasarkan pada hipotesis yang diajukan, maka metode statistik yang digunakan adalah two way Anova dan t-test. Pertimbangan untuk menggunakan two way Anova adalah terdapatnya dua variabel bebas yaitu variabel pendidikan karakter yang berskala nominal. Sedangkan variabel terikat yaitu variabel sikap etis berskala interval.

Sebelum data dianalisis, terlebih dahulu dilakukan uji prasyarat, meliputi: uji normalitas dan uji homogenitas varian.

\section{a. Uji Normalitas}

Uji normalitas data dimaksudkan untuk memperlihatkan bahwa data sampel berasal dari 
populasi yang berdistribusi normal. Teknik yang digunakan untuk menguji normalitas data adalah uji Kolmogorof-Smirnov. Uji normalitas data dilakukan dengan program SPSS for windows. Kriteria yang digunakan yaitu jika signifikansi $>0,05$, maka disimpulkan bahwa data berdistribusi normal, sebaliknya, jika signifikansi $<0,05$, maka disimpulkan bahwa data tidak terdistribusi secara normal.

\section{b. Uji Homogenitas Varian}

Uji homogenitas dimaksudkan untuk memperlihatkan bahwa dua atau lebih kelompok data sampel berasal dari populasi yang memiliki variansi yang sama. Teknik yang digunakan untuk menguji homogenitas data adalah uji levene's (levene's test of equity of error variance). Uji homogenitas menggunakan program SPSS 2,0 for windows. Kriteria yang digunakan yaitu jika signifikansi $>0,05$, maka disimpulkan bahwa varian kelompok data adalah sama, sebaliknya, jika signifikansi $<0,05$, maka disimpulkan bahwa varian kelompok data adalah berbeda.

\section{HASIL PENELITIAN}

Berdasarkan hasil analisis data, secara statistik diketahui bahwa pendidikan karakter dalam pembelajaran akuntansi keuangan tidak berpengaruh terhadap sikap etis mahasiswa. Hal ini ditunjukkan dari hasil uji-t, nilai signifikansi variabel pendidikan karakter lebih besar dari 0,05 (sig 0,652 > 0,05). Oleh karena itu hipotesis pertama (H1) yang menyatakan pendidikan karakter dalam pembelajaran akuntansi keuangan berpengaruh terhadap sikap etis mahasiswa ditolak. Kesimpulan ini bermakna bahwa kelas yang diberi muatan pendidikan karakter dalam proses pembelajaran akuntansi keuangan memiliki sikap etis yang sama dengan kelas yang melakukan proses pembelajaran tanpa muatan pendidikan karakter. Pada statistik deskriptif (Tabel 4.3) terlihat bahwa rata-rata skor sikap etis kelompok eksperimen berjumlah 30,22 sedangkan skor rata-rata sikap etis kelompok kontrol adalah 29,77. Hal ini bermakna bahwa kelompok yang diberi muatan pendidikan karakter dalam proses pembelajarannya akan memiliki sikap etis yang sedikit lebih baik dibandingkan kelas yang tidak diberi integrasi pendidikan karakter.

\section{PEMBAHASAN}

Berdasarkan uji hipotesis, diperoleh hasil bahwa pendidikan karakter tidak berpengaruh terhadap sikap etis mahasiswa. Hasil uji statistik t-test menunjukkan signifikansi 0,652 lebih besar dari 0,05. Data deskriptif menunjukkan ratarata skor sikap etis kelompok eksperimen sebesar 30,22 sedangkan rata-rata skor sikap etis kelompok kontrol sebesar 29,77.

Dari data tersebut terlihat bahwa tidak ada perbedaan skor sikap etis antara kelompok eksperimen yang diberi perlakukan integrasi pendidikan karakter dengan skor sikap etis kelompok kontrol yang diajar tanpa muatan pendidikan karakter. Artinya, mahasiswa yang menempuh mata kuliah akuntansi keuangan menengah I pokok bahasan piutang dan persediaan samasama memiliki respons yang baik terhadap isuisu etika yang sesuai dengan prinsip etika kode etik Ikatan Akuntan Indonesia.

Kesamaan sikap etis yang dimiliki oleh kedua kelompok yang mendapat perlakuan berbeda di atas, kemungkinan disebabkan oleh tiga hal, yaitu (1) pemahaman yang dimiliki oleh mahasiswa tentang hal baik yang harus dilakukan, dan hal buruk yang harus ditinggalkan, (2) pengetahuan yang dimiliki oleh mahasiswa tentang kejadian dilema akuntansi dalam sebuah 
perusahaan, dan (3) karakter yang sudah terbentuk oleh lingkungan keluarga, masyarakat, dan sekolah sebelum mahasiswa menempuh pendidikan di perguruan tinggi.

Hasil penelitian ini mendukung temuan Tikollah, dkk (2006) yang menyimpulkan bahwa terdapat fondasi yang kuat dalam memengaruhi sikap etis mahasiswa, yaitu pengetahuan terhadap kebaikan dan keburukan. Hal ini sejalan juga dengan teori sikap yang didefinisikan oleh Fishbein \& Ajzen, Oskamo, Petty \& Cacioppo dalam Azwar (2010 : 6), dan Jogiyanto (2007: 36) yang menunjukkan bahwa secara garis besar sikap berada pada ranah pemikiran, belum sampai pada perilaku, sikap memengaruhi perilaku melalui proses pengambilan keputusan yang teliti dan beralasan serta terencana.

Pemahaman mahasiswa tentang kebaikan dan keburukan, menjadi dasar mahasiswa dalam bersikap sesuai etika. Farhan (2009:11) mendefinisikan etika sebagai nilai-nilai tingkah laku atau aturan-aturan tingkah laku yang diterima dan digunakan oleh individu. Bertens (2002:6) mendefinisikan etika sebagai ilmu tentang yang baik atau buruk. Sehingga mahasiswa yang sudah memiliki pemahaman tentang hal yang baik atau buruk, akan cenderung bersikap dan berperilaku sesuai etika.

Kejadian dilema akuntansi yang dijumpai mahasiswa dalam penelitian ini disikapi dengan berpegang kepada prinsip kebaikan dan keburukan yang sudah dipahami. Mahasiswa melakukan proses berpikir sebagai bagian proses kognitif di dalam menerjemahkan sikap etis yang harus diambil dalam menyikapi dilema akuntansi yang terjadi. Mahasiswa meyakini bahwa dalam sebuah dilema yang terjadi, maka kebaikanlah yang harus didahulukan, sedangkan sikap yang berdampak pada keburukan akan selalu dihindari. Sebuah perusahaan dalam melakukan proses akuntansi akan terlibat dalam pengambilan keputusan yang sulit. Mahasiswa dengan pengetahuan yang baik mengenai kejadian dilema akuntansi yang terjadi dalam perusahaan akan melakukan proses berpikir yang jernih, kemudian merasakan dalam dirinya kejadian dilema tersebut, yang pada akhirnya diwujudkan dalam aksi sikap yang sesuai dengan pemahaman tentang kebaikan dan keburukan. Artinya dalam kondisi sulit saat menghadapi dilema akuntansi, mahasiswa cenderung melakukan hal-hal baik yang mengedepankan kebenaran daripada melakukan hal buruk yang dapat berakibat tidak baik bagi dirinya dan bagi perusahaan.

Pendidikan karakter yang memuat prinsip kejujuran, kecerdasan, ketangguhan dan kepedulian bagi mahasiswa diterima sebagai bagian hidupnya. Karakter yang melekat pada diri mahasiswa terbentuk sejak mereka menempuh pendidikan dasar dan menengah, baik secara formal, informal maupun non formal. Hal ini sejalan dengan definisi karakter secara bahasa yang berarti mengukir; membuat tajam; membuat dalam. Adapun berkarakter artinya berwatak, bertabiat, dan berperilaku sesuai pembawaan dan kebiasaan. Pendidikan yang diberikan oleh keluarga, masyarakat dan sekolah saat masih usia sekolah dasar dan menengah telah mengakar dan membentuk kepribadian mahasiswa sehingga terbiasa melakukan kebaikan dan meninggalkan keburukan. Guru yang bisa berarti pendidik di sekolah, orang tua di rumah, tokoh masyarakat dan pemuka agama membantu membentuk watak peserta didik. Pembentukan karakter mencakup keteladanan bagaimana sang guru berperilaku, berbicara dan bertoleransi. Hal ini sejalan dengan Kemendiknas (2010) yang mendefinisikan pendidikan karakter sebagai proses pemberian tuntunan kepada peserta didik agar menjadi manusia seutuhnya yang berkarakter dalam dimensi hati, pikir, raga, serta rasa dan karsa. 
Pendidikan karakter yang diberikan saat usia mahasiswa ternyata tidak memiliki dampak yang signifikan terhadap perubahan sikap mahasiswa. Hal ini terlihat dari sikap etis mahasiswa akuntansi antara yang diberi pendidikan karakter dengan tanpa pendidikan karakter sama-sama memiliki sikap etis yang bagus yang sesuai dengan prinsip etika kode etik Ikatan Akuntan Indonesia. Hal ini menunjukkan bahwa pendidikan karakter tidak hanya diberikan saat usia mahasiswa, namun hendaknya diberikan sejak usia dini. Pendidikan karakter yang memuat pendidikan nilai, pendidikan budi pekerti, pendidikan moral, dan pendidikan watak, hendaknya diberikan secara terus menerus dan berkelanjutan, baik di lingkungan formal (sekolah), informal (keluarga) maupun non-formal (masyarakat). Pendidikan karakter yang berjalan dengan baik dan sinergi akan mampu mengembangkan kemampuan peserta didik untuk memberikan keputusan baik-buruk, memelihara apa yang baik, dan mewujudkan kebaikan tersebut dalam kehidupan sehari-hari dengan sepenuh hati.

Kaitannya dengan sikap etis mahasiswa akuntansi, karakter yang dibawa mahasiswa sejak kecil akan berdampak pada sikap etis mahasiswa. Dilema kejadian akuntansi akan dihadapi dengan arif dan bijaksana disesuaikan dengan pengalaman etis yang dimiliki. Kebiasaan berbuat baik yang sudah menjadi ciri insan berkarakter melekat dengan baik pada mahasiswa. Proses pendidikan baik-buruk diawali pada pengetahuan (knowing), berlanjut pada rasa mencintai hal-hal baik (loving/feeling), dan berusaha untuk bertindak (action) sesuai dengan pengetahuan akan hal baikburuk, secara terus-menerus sehingga menjadi kebiasaan (habit). Hal ini sejalan dengan Lickona (1991) yang menyampaikan tiga pilar pendidikan karakter yaitu dimensi moral reasoning, moral feeling, dan moral behaviour. Hal senada juga disampaikan oleh Majid \& Andayani (2011:31) tentang pilar-pilar pendidikan karakter, yaitu moral knowing, moral loving/feeling, dan moral doing/action. Moral knowing akan mendorong peserta didik untuk mengetahui tentang yang baik dan buruk, tentang yang boleh dan dilarang, tentang yang bermanfaat dan sia-sia.

\section{SIMPULAN DAN SARAN}

Adapun kesimpulan dari hasil penelitian ini adalah pendidikan karakter dalam pembelajaran akuntansi keuangan tidak berpengaruh terhadap sikap etis mahasiswa. Adapun saran-saran yang dapat peneliti usulkan adalah sebagai berikut.

1. Bagi perguruan tinggi, integrasi pendidikan karakter perlu diterapkan secara eksplisit pada seluruh pokok bahasan mata kuliah akuntansi.

2. Bagi dosen, hendaknya bersedia dan aktif mengintegrasikan pendidikan karakter dalam pembelajaran akuntansi.

3. Bagi peneliti lain, Penelitian perlu dilanjutkan untuk menguji hubungan 2 variabel bebas. Sehingga dapat diketahui apakah salah satu variabel berfungsi sebagai variabel mediating atau moderating.

\section{DAFTAR PUSTAKA}

Arikunto, Syharsimi. 2006. Prosedur Penelitian Suatu Pendekatan Praktik (Edisi Revisi). Jakarta: Rineka Cipta.

Arsynullah, Hijru. 2010. Analisis Pengaruh Kecerdasan Emosional dan Lingkungan Kerja terhadap Kinerja Karyawan (Studi pada Karyawan PT IPMOMI Paiton). Tesis. Universitas Brawijaya Malang.

Azwar. 2010. Sikap Manusia, Teori dan Pengukurannya. Jakarta: Pustaka Pelajar.

Baihaqi. S. 2002 Analisis Pengarub EQ Karyawan terhadap Kualitas Perilaku Pelayanan 
Kepada Wajib Pajak di Kantor Pelayanan PBB: Studi Kasus pada KРPBB Kediri dan Tulungagung. Jogjakarta: FE-UGM.

Bertens, K. 2002. Etika. Jakarta: Gramedia Pustaka Utama.

Berkowitz, Marvin. Character Educator. 1998. Character Partnership.

Brooks, Leonard J. Dunn, Paul. 2011. Etika Bisnis dan Profesi untuk direktur, Eksekutif, dan Akuntan. Jakarta: Salemba Empat.

Dahlan. 2001. Kamus Istilah Populer. Surabaya: Arkola.

Dann, Jill. 2002. Mengenal Kecerdasan Emosional dalam Seminggu. Jakarta: Prestasi Pustaka.

Direktorat Jenderal Pendidikan Tinggi, Kementerian Pendidikan Nasional. 2010. Draft Grand Design Pendidikan Karakter. Edisi 23 Oktober 2010.

Emzir. 2008. Metodologi Penelitian Pendidikan. Kuantitatif dan Kualitatif. Jakarta: Raja Grafindo Persada.

Farhan, Djuni. 2009. Etika dan Akuntabilitas Profesi Akuntan Publik. Malang: Inti Media.

Goleman, Daniel. 2005. Kecerdasan Emosional. Jakarta: Gramedia Pustaka Utama.

Goleman, Daniel. 1999. Kecerdasan Emosi untuk Mencapai Puncak Prestasi. Jakarta: Gramedia Pustaka Utama.

Hall, James, A. 2007. Accounting Information System. Jakarta: Salemba Empat.

Hiltebeitel M. Kenneth and Scott K. 1992. An Assessment of Ethics Instruction in Accounting Education. Journal of Business Ethics 11:37-46, 1992.

IAI. 1998. Prosiding Kongres VIII Ikatan Akuntan Indonesia. Jakarta, 23-25 September 1998.

Jihad, Asep dan Haris Abdul. 2009. Evaluasi Pembelajaran. Yogyakarta: Multi Press.
Jones, T. M. 1991. Ethical Decision Making by Individuals in Organization: An Issues Contingent Model. Academic of Management Review, Vo. 16 No. 2, hal 366-395. Kamus Psikologi. 2010. Jakarta: Widyatama. Kertajaya, Hermawan: Grow with Character, the Story. Jakarta: Gramedia Pustaka Utama.

Kemendiknas. 2010. Grand Desain Pendidikan Karakter.http://katresna72.worpress.com/ 2010/10/23/grand-design-pendidikan-karakter, diakses 23 Maret 2010.

Lickona, Thomas. 1991. Educating for Character: How Our School Can Teach Respect and Responsibility. New York: Bantam Book.

Ludigo dan Machfud. 1999. Persepsi Akuntansi dan Mahasiswa tentang Etika Bisnis. Jurnal Riset Akuntansi Indonesia. Vol. 2, No. 1, Hal. 1-19.

Majid, Abdul dan Andayani, Dian. 2011. Pendidikan Karakter Perspektif Islam. Bandung: Rosda.

Muchlas, Samani dan Hariyanto. 2011. Pendidikan Karakter, Konsep, dan Model. Bandung: PT Remaja Rosdakarya.

Muslich, Masnur. 2011. Pendidikan Karakter: Menjawab Tantangan Krisis Multidimensional. Jakarta: Bumi Aksara.

O'Leary, C. 2009. An Empirical Analysis of the Positive Impact of Ethics Teaching on Accounting Student. Journal Accounting Education, 18:4, pp. 505-520.

Partanto, Pius A. Barry, M. Dahlan. 2001. Kamus Ilmiah Populer. Surabaya: Arkola.

Ronnie, Danni M. 2006. The Power of Emotional \& Adversity Quotient for Teachers. Bandung: Penerbit Hikmah.

Robinson. Dave \& Garraft Chris. 2004. Seri Mengenal dan Memahami Etika. Batam. Scientific Press. 
Segal, Jeanne. 1999. Meningkatkan Kecerdasan Emosional: Panduan Praktis. Jakarta: Citra Aksara Publishing.

Stein, J.S. \& Book, E. H. 2000. Ledakan EQ: 15 Prinsip Dasar Kecerdasan Emosional Meraih Sukses. Bandung: Kaifa.

Shapiro, Lawrence E. 1998. Mengajarkan Emotional Intelligence pada Anak. Jakarta: Gramedia.

Sugiyono. 2010. Metode Penelitian Pendidikan. Pendekatan Kuantitatif, Kualitatif, dan R \& D. Jakarta: Alfabeta.

Sudjana \& Ibrahim. 2010. Penelitian dan Penilaian Pendidikan. Bandung: Sinar Baru Algensindo.

Tikollah, M. Ridwan, dkk. 2006. Pengaruh Kecerdasan Intelektual, Kecerdasan Emosional, dan Kecerdasan Spiritual terhadap Sikap Etis Mahasiswa Akuntansi (Studi pada Perguruan Tinggi Negeri di Kota Makasar Provinsi Sulawesi Selatan). SNA IX. Padang.
Universitas Negeri Malang. 2010. Pedoman Penulisan Karya Ilmiah: Skripsi, Tesis, Disertasi, Artikel, Makalah, Laporan Penelitian. Edisi Kelima. Malang.

Utami dan Indriawati. 2006. Muatan Etika dalam Pengajaran Akuntansi Keuangan dan Dampaknya terhadap Persepsi Etika Mahasiswa: Studi Eksperimen Semu. Prosiding SNA IX, Padang.

Wulandari dan Sularso. 2002. Persepsi Akuntan Pendidik dan Mahasiswa Akuntansi terhadap Kode Etik Akuntan Indonesia: Studi Kasus di Surakarta, Perspektif. Vol. 7, No. 2. Hal. 71-78.

Yani, I. 1998. Pentingnya Penegakan Etika sebagai Pendukung Terciptanya Akuntan yang Profesional. Prosiding KNA VIII, Jakarta, 23-25 September. 
Accounting and Management Journal, Vol. 2, No. 1, July 2018 